\title{
Analytical Review on Competitive Priorities for Operations under Manufacturing Firms
}

\author{
M. Prabhu' ${ }^{1}$ D , Nambirajan Thangasamy ${ }^{2}$ iD, Nabaz Nawzad Abdullah ${ }^{3}$ \\ ${ }^{1}$ Department of Business Administration, Lebanese French University (Iraq) \\ ${ }^{2}$ Department of Management Studies, School of Management, Pondicherry University (India) \\ ${ }^{3}$ Business Administration Department, Collage of Administration and Economics, University of Human Development, (Iraq) \\ bordauprabbu@lfu.edu.krd,rtnambirajan@gmail.com,nabaz.nawzad@ubd.edu.iq
}

Received: March 2019

Accepted: January 2020

\begin{abstract}
:
Purpose: To developed and introduced a measurement scale that may be useful to assess the competitive priorities practices in the manufacturing industries. The objective is to investigate the competitive priorities domains' implementation and its defining measurement items emphasizing manufacturing industries in the Union Territory of Puducherry.

Design/methodology/approach: The essential information has been gathered from 350 manufacturing firms located in Union Territory of Puducherry; most parts of the datawere gathered from best dimension working people like Operations Managers, General Managers and Directors. For analyzing the data the researchers used SPSS and LISREL 8.72 software packages. To find out the result the researchers applied Confirmatory Factor Analysis in this research work.

Findings: From the six domains analyzed the result shows that Delivery plays an important role as it occupies the first rank among the domains in competitive priority. Next to Delivery, the majority of the firms fasten more importance to Quality as it ranks second. Cost is ranked as third, while Know-how is ranked as fourth, Flexibility is ranked as fifth and Customer Focus is ranked as sixth.
\end{abstract}

Practical implications: Based on the existing recommendations on scale development literature, the authors developed the measurement scale. This measurement scale is helpful for both academicians and practitioners. In this research work, the authors used the measurement scale to measure the competitive priorities domains.

Originality/value: The research paper explains the manufacturing industries situated in the Union Territory of Puducherry. The researchers developed the measurement instrument of competitive priorities practices based on six domains namely quality, cost, delivery, flexibility, customer focus, and know-how. This research work gives innovative literature by recommendations and validating a measurement scale for the competitive priorities. The result reveals that the manufacturing enterprises in the Union Territory of Puducherry.

Keywords: competitive priorities, quality, cost, manufacturing and confirmatory factor analysis

\section{To cite this article:}

Prabhu, M., Nambirajan, T. \& Abdullah, N.N. (2020). Analytical review on competitive priorities for operations under manufacturing firms. Journal of Industrial Engineering and Management, 13(1), 38-55.

https://doi.org/10.3926/jiem.2876 


\section{Introduction}

Globalised scenario has thrown many open challenges, especially in technology-related areas. Firms engaged in manufacturing are subjected to many complexities as they have to constantly update and upgrade their technologies to gain a decisive edge over their competitors. For this purpose, they have to concentrate immensely on fixing Competitive Priorities (CP). Competitive priorities refer to the different aspects and dimensions to be engulfed by the manufacturing system of firms to cater to requirements and conditions of markets the firms endeavor to venture into (Krajewski \& Ritzman, 1993; Sudhakar \& Basariya, 2017; Ganeshkumar, Prabhu \& Abdullah, 2019). Kim and Arnold (1996) have defined competitive priorities as a comprehensive process enabling firms to draft business strategies to cater to market requirements and conditions. The conventional belief was that different competitive priorities are not compatible with each of them (Wheelwright, 1984).

Phusavat and Kanchana (2007) have hinted upon six components of competitive priority as flexibility, cost, delivery, quality, know-how and focusing customers. Competitive priorities engulf four important variables of flexibility, cost, dependability and quality (Ferdows \& De Meyer, 1990; Ward \& Duray, 2000; Vickery, Droge \& Markland, 1993; Li, 2000; Kathuria, 2000; Hayes \& Wheelwright, 1984). With time, innovation and human resource capabilities have also been included in the ambit of competitive priorities as they play a significant role in firms gaining competitive advantage (Wood, Ritzman \& Sharma, 1990).

Firms strive hard to gain competitiveness in the market to make them unique and distinct from competitors and towards accomplishing these endeavors they have to develop their potentials to adapt to complex environmental conditions for which they have to be competent to adjust their priorities such as speed of delivery, cost, dependability, quality, flexibility and innovation such that they are equipped to satisfy different market needs and conditions (Carpinetti, Gerolamo \& Dorta, 2000).

\section{Literature Review}

Quality is an important factor that has a positive impact on the performance of the manufacturing industries. It helps to improve the level of performance in the organization (Deming, 1982, 1986; Motwani, Mahmoud \& Rice, 1994; Nambirajan \& Prabhu, 2010). Zhao, Yan Yeung and Zhou (2002) studied the strengths and opportunities available with 130 Chinese enterprises, the authors concluded that the skill to innovate, flexibility, post-sales services and quality will be the most important CP factors on those the Chinese firms must focus for the forthcoming five years. Though the Chinese firms have got tremendous strength in these areas, they lack behind others in the capacity to be innovative. Kathuria, Porth and Kathuria (2010) undertook a study to explore the CP of 78 Indian manufacturing enterprises. They employed the paired samples t-tests and multivariate analysis and found out that both cadres of the managerial staff members had an identical opinion in placing high emphasison quality followed by delivery. Not much emphasis was placed on product variety and dynamism to bring innovative changes in the product mix, as far as CP strategy crafting is concerned.

Ibrahim (2010) conducted a study on the IT sector to explore the operational strategies that could be followed to boost the turnover of the companies. Using Correlation and Logistic Regression, the authors explored the relationship between past turnover accomplished and operational strategies forming part of the CP of the enterprise. The study revealed that quality was the most important factor influencing the turnover of the enterprise, while the customer-oriented approach focuses due importance to servicing them as the most indispensable aspects of boosting turnover. Tawfik-Mady (2008) conducted a study on Kuwaiti manufacturing enterprises to explore their important CP policies. The study also endeavored to assess the effect of plant size and industry type on CP. They conducted this study on 62 Kuwaiti enterprises belonging to refractors and food processing industries. Small and medium enterprises placed utmost importance on the delivery aspect, while the larger enterprises placed paramount importance on flexibility. The two industries surveyed placed paramount importance on delivery and quality aspects of $\mathrm{CP}$, while they attach the least priority to innovativeness and flexibility aspects.

Nagabhushana and Shah (1999) study reveal that Indian firms attach paramount importance to cost, followed by quality and delivery and they attach the least importance to flexibility. However, the enterprises are endeavoring to accomplish these objectives without making additional investments and major changes in the pattern of operation. Kathuria, Porth and Joshi (1999) used five domains that are Cost, Quality-of-Conformance, Quality-of-Design, 
Flexibility and Delivery to measure the competitive priority. The study revealed that the General Managers bestow importance to external factors such as consumer demand and competitive challenges while trying to make the decision. However, the manufacturing managers confer more importance to internal factors such as cost control and manufacturing flexibilities in decision making.

Lucia Avella (1999) studied the manufacturing strategies of manufacturing enterprises in Spain and compared it with the USA and Europe manufacturing industries. The Spanish manufacturing units concentrated more on on-time deliveries. Whereas, the American and European manufacturing industries gave more importance to high quality and low cost. Kenneth K. Boyer and Mark Pagell (2000) examined the measures used in operational management. Specifically, they studied the measures used in operational strategies and Advanced Manufacturing Technology. They have made a methodological analysis of the strengths and weaknesses of these two measures and also propagated suitable suggestions to improve them in the future.

Mojtahedzadeh and Arumugam (2011) found that customer focus is an essential aspect of the organization's success. The aim of customer focus is to satisfy the customer's needs and demand and provide the requisite. Dangayach and Deshmukh (2003) examined the various manufacturing strategies in four industrial sectors namely electronics, automobile, machinery and process industry in India. Various domains such as competitive priorities, activities of improvement and order winners were considered in that study. The results show that in India all four manufacturing sectors give first priority to quality. They also found in India, automobile manufacturers are highly fascinated by new innovation, rapid new product development and continuous improvement which are the positive sign for the automobile industries in India for their future growth. Haeri (2005) found that customers' suggestions and feedbacks help the manufacturing units to be successful in the business. He suggested that those who have a strong relationship with the customers only have a higher level of success and it helps them to make a decision at the right time.

Phusavat and Kanchana (2008) conducted a study among the manufacturing and service-providing industries in Thailand about the present and future competitive priority positions and they compared the difference between those two sectors. Questionnaires are used to obtain the information from the respondent, each instrument contains 31 variables grouped into 6 domains namely quality, cost, customer-focus, delivery/provision, flexibility and know-how. They found delivery/service provisions are the number one competitive domains for both the manufacturing and service-providing industries. They also found that in future the quality plays a first and most important role in Thailand's manufacturing and service industries. Li, Qi, Tian and Li (2008) conducted a study among the Chinese manufacturing industries about the cumulative relationship of manufacturing strategies. The results revealed that there is a slight difference between global enterprises and Chinese manufacturing enterprises in manufacturing strategies. It was also found that the Chinese manufacturing enterprises enjoy an advantage in quality, flexibility and innovation over the global enterprises.

Regarding the competitive priority construct, many authors have included factors such as quality, delivery, cost, and flexibility while a few of them have used the factors of Customer focus and Know-how. Hence, the researchers have included all these six factors under the construct of competitive priority to make the study more comprehensive. Based on the above literature review the researchers formulated the objective of studying the competitive priorities domains' and it's defining measurement items emphasizing manufacturing units in Puducherry, India. The authors developed and introduced a measurement scale that may be useful to assess the competitive priorities practices in the manufacturing industries.

\section{Research Methodology}

The proposed research study is descriptive in nature, covering manufacturing industries situated in the Union Territory of Puducherry, India. Both primary and secondary data have been used for this research. Primary data was collected using a well-structured questionnaire, which was administered personally to the executives of manufacturing undertakings in the Union Territory of Puducherry, India. Secondary data was collected from the findings of Published Papers, Articles, Books, Prior Studies, Organizations' Bulletins, and Annual Reports of the manufacturing units and from various web sites. The Personal Interview method was employed to collect data. 


\subsection{Sample Population and Sampling Technique}

The Union Territory of Puducherry is the sample frame for the study. All the four regions of the Union Territory namely, Puducherry, Karaikal, Yanam, and Mahe. With a current population of 11.1 lakhs and the existence of well-established 72 large scale industries, 176 medium scale industries and 7950 small scale industries and this number being on the ever increase, offers tremendous scope for choosing Puducherry as the sample frame for the study. The sampling technique used for the study is the Simple Random sampling method. The names of 8588 units engaged in manufacturing and 365 sample units were drawn from this list using the Lottery Method. Out of 365 questionnaires that were administered, 15 were rejected for invalid and incomplete responses and 350 valid questionnaires were considered for further analysis.

\subsection{Data Analysis Tools}

Both traditional and sophisticated statistical tools were applied for data analysis. The data collected were fed into Excel sheet and the statistical packages of SPSS 19 Version and LISREL were employed. The statistical tools of Mean, Standard Deviation and Confirmatory Factor Analysis were used to analyze the data and arrive at meaningful conclusions.

\subsection{Data Examination and Preparation}

This section explains how characteristics of the data were studied for consistency with distributional assumptions. Checking the reliability and validity of the research instrument is more important before starting any kind of analysis, especially in respect of conducting multivariate analysis with confirmative factor analysis. The first step shall be to ensure that the data is properly prepared and thoroughly examined. This will help to minimize measurement error and maximize the validity and reliability of the data. The requirement level of data can be verified using many tests such as Reliability, Communality, Normality, Multicollinearity, Individual item reliability, Construct reliability, Convergent validity, and Discriminant Validity. These tests shall study the entire anatomy of the data set.

\subsection{Reliability}

The reliability of the questionnaire was tested by utilizing the Cronbach alpha. It can be found that the Cronbach's $\alpha$ coefficient of all the items included under the Competitive Priority domain range from 0.804 to 0.916 . This indicates that all the items included under the six factors of the CP domain command a good degree of internal consistency.

\subsection{Communality}

Higher communalities are better at the time of model formulation and the minimum threshold limit for establishing the Communality of the data is 0.5 . Variables with a communality value of less than 0.5 should be removed. The communality value in respect of low defect rate and Continuous improvement is below 0.5 and hence this item is dropped from the study.

\subsection{Normality}

In general terms, normality specifies that the data are normally distributed. Normally distributed data will result in the formation of a bell-shaped curve. Data with high Normality will yield a mean of zero and a standard deviation of one. (Groebner \& Shannon, 1990; Lewis-Beck, Bryman and Liao, 2004). The normality of data is indispensable for arriving at CFA using LISREL and lack of normality will adversely affect the goodness-of-fit indices and standard error (Hair, Black, Babin, Anderson \& Tatham, 2006; Jöreskog \& Sörbom, 1996; Baumgartner \& Homburg, 1996). Hence, the normality of data has been tested and the results are discussed in the following sections. The normality of data can be tested using Kurtosis and Skewness. Skewness may be positive (if the tail of the curve points towards left) or negative (if the tail of the curve points towards the right) (Groebner \& Shannon, 1990). Similarly, Kurtosis indicates the peakedness of the distribution curve. Positive Kurtosis will lead to the curve with a high peak, while negative Kurtosis will lead to a flat curve (Everitt, 2006). Kurtosis should be in the range of +3 and -3 , while Skewness should be in the range of +1 to -1 (Lewis-Beck, 
Bryman \& Liao, 2004; Hair et al. 2006). From table 11, the normality tests are conducted for six domains of competitive priorities such as Quality, Cost, Delivery, Flexibility, Customer Focus and Know-how the results show that all the value is within the range of -2 to +2 of skewness and kurtosis. This indicates that the above six domains are considered to be normally distributed.

\subsection{Multicollinearity}

Multicollinearity presents if two or more independent variables assess the same thing. Tabachnick and Fidell (2007) suggested that the correlation values exceed 0.90 in respect of variables in the same data set, which can cause statistical problems and such variables should be dropped from the study. It can be observed from the analysis the correlation values in respect of all 28 variables do not exceed the prescribed value of 0.90 , and hence, it can be concluded that there are no multicollinearity problems in the data.

\section{Analysis and Result}

This section describes the Individual item reliability, Construct reliability, Convergent validity, Discriminant validity, Independent measurement model, First-order Confirmatory Factor Analysis and second-order Confirmatory Factor Analysis.

\subsection{Independent Measurement Model}

Six independent measurement factors have been used to measure the opinion of the respondents about the competitive priorities of the manufacturing firms. The independent factor of Quality in competitive priorities domain was evaluated using five items of CQPe, CQPro, CQEn, CQCer and CQPd. Of these five items, the factor loadings in respect of the item Product durability are less than 0.5. Hence this item is dropped from the study and $\mathrm{CFA}$ is run based on the remaining four items. Four indicators namely, CCLo, CCVa, CCQu, and CCAc were used to measure the cost domain in competitive priorities. Five indicators of CDFa, CDRi, CDRig and CDDe have been utilized to measure the Delivery factors in competitive priorities. Table 3 shows the results of the Independent Measurement Model of Delivery factors. Of these five items, the factor loadings in respect of the item the Ontime delivery is less than 0.5. Hence this item is dropped from the study and CFA is run based on the remaining four items. The responses of the executives of manufacturing units about Flexibility were measured using the four indicators of $\mathrm{CFDe}, \mathrm{CFV}, \mathrm{CFPr}$ and $\mathrm{CFBr}$ as constituents of the Independent Measurement Model. Four indicators of CCFA, CCFPro, CCFC and CCFMea have been used to measure the Customer focus domain in competitive priorities of the manufacturing firms. Six indicators of CKKno, CKCon, CKPro, CKTr and CKRd were utilized to measure the Know-how domain in competitive priorities of the manufacturing firms. Table 6 shows the results of the Independent Measurement Model of Know-how domain. Of these six items, the factor loadings in respect of the item Creativity is less than 0.5. Hence this item is dropped from the study and CFA was run based on the remaining five items.

The reliability of the estimates of extracted variance was computed, with indicator standardized loadings and measurement errors (Hair, Anderson, Tatham \& Black, 1998; Shim, Eastlick, Lotz \& Warrington, 2001; Jarvis, MacKenzie \& Podsakoff, 2003). CFA takes care of confirming the designed factor arrangement. Results indicate that the factor arrangement is highly significant. Hence, it can be concluded that all the items included under this domain aptly fit into the said domain. Similarly, the reliability and validity of the model being confirmed by CR being in excess of 0.70 and AVA being in excess of 0.50 respectively. Good reliability and validity of the model signify the prevalence of satisfactory unidimensionality level. The calculated values of GFI and RMSEA are satisfied the desired range of above 0.90 for GFI and 0.08 to 0.10 in respect of the RMSEA. Further, the values of AGFI, CFI and NFI far exceed the desired threshold limit of 0.90 . This signifies the mediocre fitness of the model. Hence, the results confirm the acceptability of the derived model.

Figure 1 portrays the model for Quality (cp1), Cost (cp2), Delivery (cp3) Flexibility (cp4), Customer focus (cp5) and Know-how (cp6). It can be inferred from the above figure that the factor loadings in respect of all the items are well above the requisite quantum of 0.50 . Hence, it can be said that all these items are significantly important for the model. 


\begin{tabular}{|c|c|c|c|c|c|c|c|c|}
\hline \multicolumn{2}{|l|}{ Table } & \multicolumn{5}{|c|}{$\begin{array}{l}\text { Results of Independent Measurement Model } \\
\text { (Confirmatory Factor Analysis) }\end{array}$} & \multicolumn{2}{|c|}{$\begin{array}{l}\text { Results of } \\
\text { Reliability Test }\end{array}$} \\
\hline Item & Items & $\begin{array}{l}\text { Standard } \\
\text { Solutions }\end{array}$ & $\begin{array}{l}\text { Factor } \\
\text { estimate }\end{array}$ & $\mathrm{t}$ - value & $\begin{array}{c}\text { Error } \\
\text { variance }\end{array}$ & $\mathbf{R}^{2}$ & CR & AVE \\
\hline \multicolumn{9}{|c|}{ Quality-cp1 } \\
\hline Performance quality & CQPe & 0.80 & 0.76 & 16.85 & 0.37 & 0.63 & \multirow{5}{*}{0.854} & \multirow{5}{*}{0.598} \\
\hline Product Reliability & CQPro & 0.90 & 0.88 & 20.04 & 0.19 & 0.81 & & \\
\hline Environmental aspect & CQEn & 0.69 & 0.74 & 13.92 & 0.53 & 0.47 & & \\
\hline Certification & CQCer & 0.69 & 0.67 & 13.98 & 0.52 & 0.48 & & \\
\hline Product durability & CQPd & \multicolumn{5}{|c|}{-} & & \\
\hline \multicolumn{9}{|c|}{ Cost- cp2 } \\
\hline Low costs & CCLo & 0.73 & 0.68 & 14.69 & 0.46 & 0.54 & \multirow{4}{*}{0.831} & \multirow{4}{*}{0.553} \\
\hline Value added costs & $\mathrm{CCVa}$ & 0.84 & 0.77 & 17.47 & 0.3 & 0.70 & & \\
\hline Quality costs & CCQu & 0.70 & 0.69 & 13.94 & 0.5 & 0.50 & & \\
\hline Activity based measurement & CCAc & 0.69 & 0.53 & 13.68 & 0.52 & 0.48 & & \\
\hline \multicolumn{9}{|c|}{ Delivery- cp3 } \\
\hline Fast delivery & $\mathrm{CDFa}$ & 0.66 & 0.62 & 12.83 & 0.57 & 0.43 & \multirow{5}{*}{0.837} & \multirow{5}{*}{0.564} \\
\hline Right quality & CDRi & 0.80 & 0.72 & 16.71 & 0.36 & 0.64 & & \\
\hline Right amount & CDRig & 0.84 & 0.78 & 17.81 & 0.29 & 0.71 & & \\
\hline Dependable promises & CDDe & 0.69 & 0.64 & 13.78 & 0.52 & 0.48 & & \\
\hline On-time delivery & CDOt & & & - & & & & \\
\hline \multicolumn{9}{|c|}{ Flexibility- cp4 } \\
\hline Design adjustments & CFDe & 0.64 & 0.61 & 12.15 & 0.59 & 0.41 & \multirow{4}{*}{0.808} & \multirow{4}{*}{0.515} \\
\hline Volume change & $\mathrm{CFVO}$ & 0.83 & 0.81 & 16.89 & 0.3 & 0.70 & & \\
\hline Product Mix changes & CFPr & 0.73 & 0.71 & 14.29 & 0.47 & 0.53 & & \\
\hline Broad product line & $\mathrm{CFBr}$ & 0.65 & 0.69 & 12.49 & 0.57 & 0.43 & & \\
\hline \multicolumn{9}{|c|}{ Customer focus- cp5 } \\
\hline After sales service & CCFA & 0.58 & 0.63 & 11.14 & 0.66 & 0.34 & \multirow{4}{*}{0.852} & \multirow{4}{*}{0.595} \\
\hline Product customization & CCFPro & 0.82 & 0.81 & 17.51 & 0.33 & 0.67 & & \\
\hline Customer information & CCFC & 0.82 & 0.80 & 17.49 & 0.33 & 0.67 & & \\
\hline Measurement of satisfaction & CCFMea & 0.84 & 0.80 & 18.06 & 0.30 & 0.70 & & \\
\hline \multicolumn{9}{|c|}{ Know how- cp6 } \\
\hline Knowledge management & CKKno & 0.72 & 0.76 & 15.06 & 0.48 & 0.52 & \multirow{6}{*}{0.895} & \multirow{6}{*}{0.633} \\
\hline Continuous learning & CKCon & 0.87 & 0.89 & 19.94 & 0.24 & 0.76 & & \\
\hline Problem solving skills & CKPro & 0.83 & 0.81 & 18.56 & 0.31 & 0.69 & & \\
\hline Training/education & $\mathrm{CKTr}$ & 0.83 & 0.85 & 18.49 & 0.31 & 0.69 & & \\
\hline $\mathrm{R} \& \mathrm{D}$ & CKRd & 0.71 & 0.72 & 14.87 & 0.49 & 0.51 & & \\
\hline Creativity & $\mathrm{CKCr}$ & & & - & & & & \\
\hline
\end{tabular}

Table 1. Independent Measurement Model of CP 


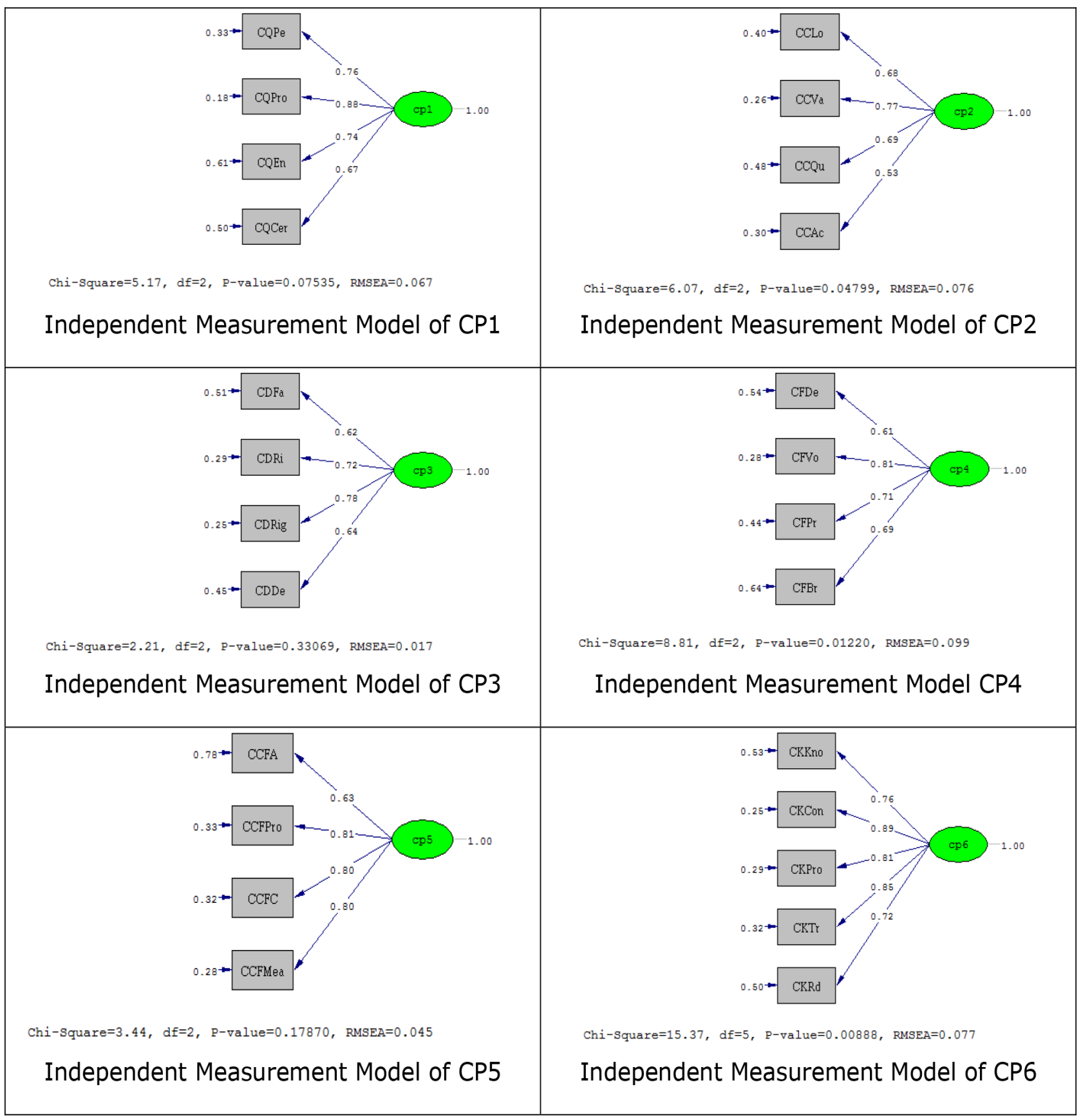

Figure 1. Independent Measurement Model of CP

\subsection{First Order Measurement Model of Competitive Priorities (CP)}

Six components of delivery, customer focus, flexibility, cost, quality, and know-how have been used to assess the $\mathrm{CP}$ of the studied manufacturing firms and these six factors have been adequately validated and included in the independent measurement model through the conduct of First Order Measurement Model Confirmatory Factor Analysis. This will enable the researcher to scrutinize the model precisely. Values of $\mathrm{X}^{2}(417.05), \mathrm{P}(0.00), \mathrm{X}^{2} / \mathrm{df}$ (1.60), GFI(0.91), AGFI(0.89), CFI(0.99) and RMSEA (0.042) as displayed by the first-order measurement model reveals that all indispensable conditions for valid item-wise reliability of first-order measurement model has been catered to. Proceeding further, the validity of the comprehensive model has to be tested and the results of this test are presented in Table 2 . 


\begin{tabular}{|c|c|c|c|c|c|c|c|c|}
\hline Table & \multicolumn{6}{|c|}{$\begin{array}{l}\text { Results of First Order Measurement Model } \\
\text { (Confirmatory Factor Analysis) }\end{array}$} & \multicolumn{2}{|c|}{$\begin{array}{l}\text { Results of } \\
\text { Reliability Test }\end{array}$} \\
\hline Items & Items & $\begin{array}{l}\text { Standard } \\
\text { Solutions }\end{array}$ & $\begin{array}{l}\text { Factor } \\
\text { estimate }\end{array}$ & $\mathrm{t}$ - value & \begin{tabular}{c|c} 
Error \\
variance
\end{tabular} & $\mathbf{R}^{2}$ & CR & AVE \\
\hline \multicolumn{7}{|c|}{ Quality } & \multirow{5}{*}{0.857} & \multirow{5}{*}{0.602} \\
\hline Performance quality & CQPe & 0.8 & 0.76 & 17.14 & 0.36 & 0.64 & & \\
\hline Product Reliability & CQPro & 0.87 & 0.86 & 19.64 & 0.24 & 0.76 & & \\
\hline Environmental aspect & CQEn & 0.71 & 0.76 & 14.46 & 0.5 & 0.50 & & \\
\hline Certification & CQCer & 0.71 & 0.70 & 14.68 & 0.49 & 0.51 & & \\
\hline \multicolumn{7}{|c|}{ Cost } & \multirow{5}{*}{0.832} & \multirow{5}{*}{0.554} \\
\hline Low costs & CCLO & 0.72 & 0.67 & 14.47 & 0.49 & 0.51 & & \\
\hline Value added costs & CCVa & 0.81 & 0.75 & 17.03 & 0.35 & 0.65 & & \\
\hline Quality costs & $\mathrm{CCQu}$ & 0.72 & 0.70 & 14.65 & 0.48 & 0.52 & & \\
\hline Activity based measurement & CCAc & 0.73 & 0.56 & 14.91 & 0.47 & 0.53 & & \\
\hline \multicolumn{7}{|c|}{ Delivery } & \multirow{5}{*}{0.838} & \multirow{5}{*}{0.566} \\
\hline Fast delivery & $\mathrm{CDFa}$ & 0.68 & 0.64 & 13.57 & 0.54 & 0.46 & & \\
\hline Right quality & CDRi & 0.8 & 0.72 & 17.12 & 0.36 & 0.64 & & \\
\hline Right amount & CDRig & 0.81 & 0.75 & 17.50 & 0.34 & 0.66 & & \\
\hline Dependable promises & CDDe & 0.71 & 0.66 & 14.48 & 0.49 & 0.51 & & \\
\hline \multicolumn{7}{|c|}{ Flexibility } & \multirow{5}{*}{0.808} & \multirow{5}{*}{0.515} \\
\hline Design adjustments & CFDe & 0.65 & 0.62 & 12.68 & 0.57 & 0.43 & & \\
\hline Volume change & $\mathrm{CFVO}$ & 0.83 & 0.81 & 17.49 & 0.31 & 0.69 & & \\
\hline Product Mix changes & CFPr & 0.72 & 0.70 & 14.36 & 0.48 & 0.52 & & \\
\hline Broad product line & $\mathrm{CFBr}$ & 0.65 & 0.69 & 12.72 & 0.57 & 0.43 & & \\
\hline \multicolumn{7}{|c|}{ Customer focus } & \multirow{5}{*}{0.850} & \multirow{5}{*}{0.592} \\
\hline After sales service & CCFA & 0.59 & 0.64 & 11.41 & 0.65 & 0.35 & & \\
\hline Product customization & CCFPro & 0.81 & 0.81 & 17.52 & 0.34 & 0.66 & & \\
\hline Customer information & CCFC & 0.81 & 0.80 & 17.54 & 0.34 & 0.66 & & \\
\hline Measurement of satisfaction & CCFMea & 0.84 & 0.80 & 18.21 & 0.3 & 0.70 & & \\
\hline \multicolumn{7}{|c|}{ Know how } & \multirow{6}{*}{0.895} & \multirow{6}{*}{0.634} \\
\hline Knowledge management & CKKno & 0.73 & 0.77 & 15.50 & 0.46 & 0.54 & & \\
\hline Continuous learning & CKCon & 0.87 & 0.89 & 20.03 & 0.24 & 0.76 & & \\
\hline Problem solving skills & CKPro & 0.83 & 0.80 & 18.42 & 0.32 & 0.68 & & \\
\hline Training/education & $\mathrm{CKTr}$ & 0.83 & 0.85 & 18.57 & 0.31 & 0.69 & & \\
\hline$R \&$ & CKRd & 0.71 & 0.72 & 14.78 & 0.5 & 0.50 & & \\
\hline
\end{tabular}

Table 2. First Order Measurement Model of CP

Notes:

Construct realiability y $=(\Sigma \text { Standardized loadings })^{2} /\left[(\Sigma \text { Standardized loadings })^{2}+\Sigma e j\right]$

Average variance extracted $(\mathrm{AVE})=\Sigma(\text { Standardized loadings })^{2} /\left[\Sigma(\text { Standardized loadings })^{2}+\sum e j\right]$

where $e j$ is the measurement error. 


\begin{tabular}{|l|r|r|r|}
\hline \multicolumn{1}{|c|}{ Construct } & Item reliability & Construct reliability & AVE \\
\hline Suggested value & $>0.5$ & $>0.6$ & $>0.5$ \\
\hline
\end{tabular}

Table 3. Reliability (Fornell \& Larcker, 1981)

Factor loadings have been used to arrive at the reliability of individual items (Camison \& Villar 2010). Carmines and Zeller (1979) have propagated that factor loadings should exceed 0.70 to constitute a valid model. However, some authors such as Barclay, Higgins and Thompson (1995) and Chin (1998) have opined that factor loadings in excess of 0.5 are sufficient to constitute a valid model. The above table portrays that factor loadings in respect of all the variables well exceed the minimum prescribed limits, suggesting that all factors are possessing the desirable individual reliability.

Moving on, the internal consistency of items used to measure construct have to be established for which construct reliability has to be ascertained (Fornell \& Larcker, 1981). AVA should exceed 0.5 to establish the model's convergent validity while the construct reliability must exceed 0.6 and Table 3 suggests that the values in respect of construct reliability of all items well exceed the minimum required values. Hence, it can be concluded that all the items possess the needed construct reliability. Table 2 displays that the AVA value in respect of all the constructs far exceeds the minimum threshold value.

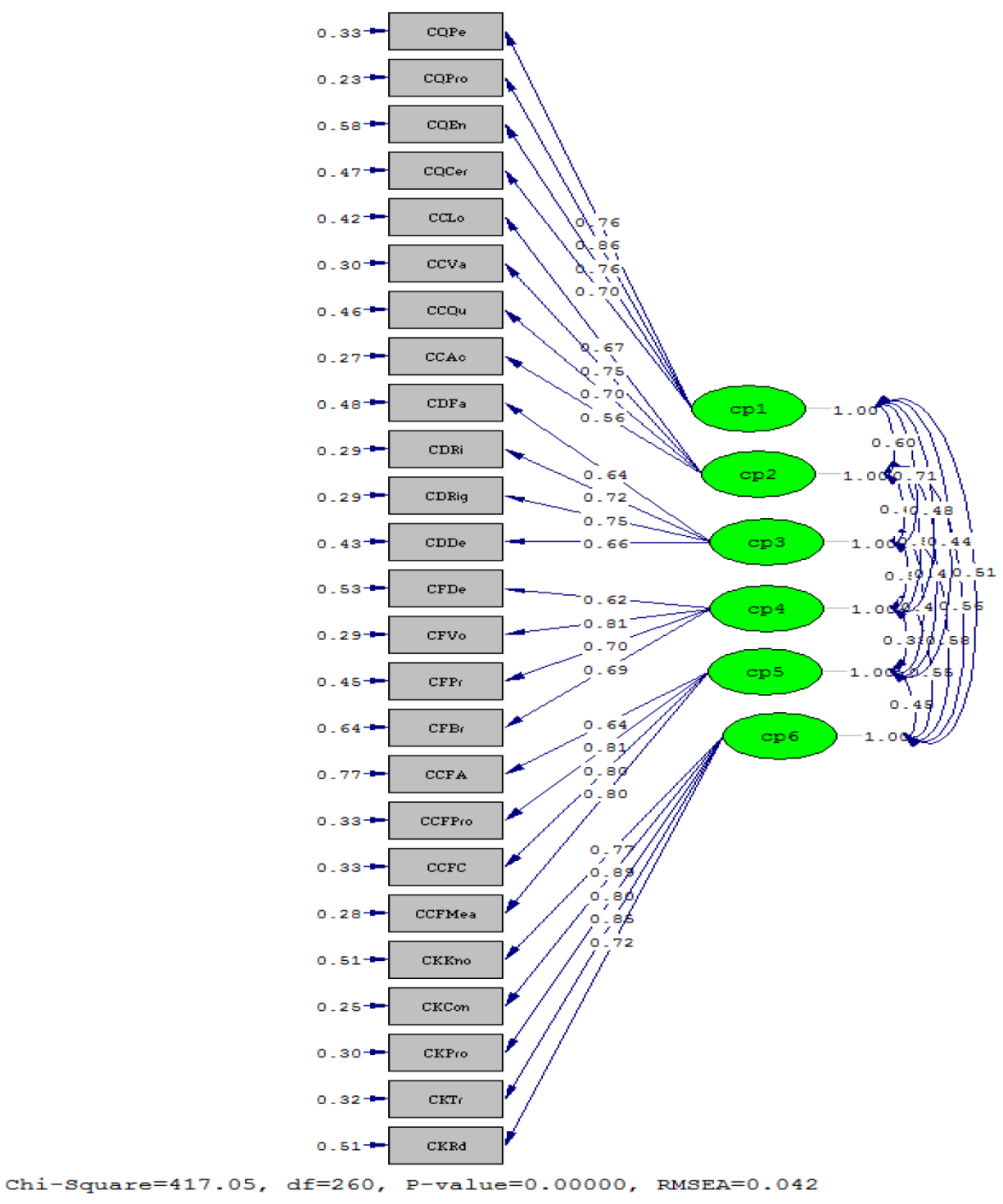

Figure 2. First Order Measurement Model of CP 
The model for Competitive priorities (cp) is shown in Figure 2. The factor loadings in respect of the items far exceed the recommended value of 0.50 and hence they are significantly important.

\subsection{Discriminant Validity}

The distinctiveness of a construct from the other constructs in a model is confirmed by discriminant validity. This validity may be verified by comparing the AVA with the square of the correlations of the constructs. Table 4 indicates that the AVA value far exceeds the square of the correlation coefficient and hence the discriminant validity of the model is confirmed (Fornell \& Larcker, 1981).

\begin{tabular}{|r|r|r|r|r|r|r|}
\hline & \multicolumn{1}{|c|}{ CP6 } & \multicolumn{1}{c|}{ CP5 } & \multicolumn{1}{c|}{ CP4 } & \multicolumn{1}{c|}{ CP3 } & \multicolumn{1}{c|}{ CP2 } & CP1 \\
\hline CP6 & $(0.633)$ & & & & & \\
\hline CP5 & 0.202 & $(0.595)$ & & & & \\
\hline CP4 & 0.302 & 0.108 & $(0.515)$ & & & \\
\hline CP3 & 0.336 & 0.16 & 0.313 & $(0.564)$ & & \\
\hline CP2 & 0.313 & 0.220 & 0.336 & 0.366 & $(0.553)$ & \\
\hline CP1 & 0.261 & 0.193 & 0.230 & 0.504 & 0.36 & $(0.598)$ \\
\hline
\end{tabular}

Table 4. Correlation Matrix of Independent Domains

Notes: Diagonal elements (values in parentheses) are the Average Variance Extracted (AVE); off-diagonal elements are the square correlations among constructs.

\subsection{Second-Order Measurement Model of Competitive Priorities (CP)}

First Order Confirmatory Factor Analysis for Competitive priorities factors have been discussed in the previous sections. The Competitive priorities construct of Quality, Cost, Delivery, Flexibility, Customer focus and Know-how has been related to Competitive priorities. It shows that the model is acceptable in First Order Confirmatory Factor Analysis. This has been tested with a second-order confirmatory factor analysis model where it is assumed that if the constructs are linked to each other. Therefore Second-Order Measurement Model of Competitive priorities (cp) is conducted in the forthcoming section.

In the measurement model and First Order model discussed earlier, six factors have been considered as independent items. These factors are one unidirectional arrow away from the observed items and have been consequently labeled as "First-Order Factors". Available theory suggests that higher-level factor is accountable for lower-level factors. The second-order model represents the Competitive priorities, which has not been measured from the respondents. Instead, the Competitive priorities derive their value from the six factors included in the firstorder model. Hence, the six factors included in the first-order model as independent items now become dependent items. This implies that the variances and covariances of these factors discontinue being the probable parameters in the model. It should be remembered that these variations and co-variations should be accounted for by the higher-order factor (Bentler, 1992; Byrne, 1988; Joreskog \& Sorbom, 1993). Consideration of formative and reflective outer model modes is an important issue for SEM. While the decision on the outer model set-up should be based primarily on theoretical grounds (Jarvis et al. 2003).

In general, statistics indicate that the fit of the second-order model is as good as that of the first-order model. The results displayed in Table 5 representing the final full second-order Competitive priorities CFA measurement model, shows that the loadings of all six first-order factors on the second-order factor are positive and significant. The model yielded a good model fit of $\mathrm{X}^{2}=444.44, \mathrm{P}=0.00, \mathrm{X}^{2} / \mathrm{df}=1.65, \mathrm{GFI}=0.91$, AGFI $=0.89$, CFI $=0.99$ and RMSEA $=0.071$.

The model for Competitive priorities (cp) is shown in Figure 3. The factor loadings in respect of all the items far exceed the recommended value of 0.50 and hence are significantly important. The results confirm that empirical data adequately fit for this second-order competitive priorities model. Based on the factors loadings of the items, 
the contribution made by the domains in respect of Competitive priorities may be ranked as Delivery, Quality, Cost, Know-how, Flexibility and Customer focus.

\begin{tabular}{|c|c|c|c|c|c|c|c|}
\hline \multicolumn{2}{|l|}{ Table } & \multicolumn{6}{|c|}{$\begin{array}{l}\text { Results of Second-Order Measurement Model } \\
\text { (Confirmatory Factor Analysis) }\end{array}$} \\
\hline Items & Items & $\begin{array}{l}\text { Standard } \\
\text { Solutions }\end{array}$ & $\begin{array}{l}\text { Factor } \\
\text { estimate }\end{array}$ & $\mathrm{t}$ - value & $\begin{array}{l}\text { Error } \\
\text { variance }\end{array}$ & $\mathbf{R}^{2}$ & $\begin{array}{l}\text { Factor } \\
\text { Estimate } \\
\text { for } \\
\text { Second } \\
\text { Order }\end{array}$ \\
\hline \multicolumn{8}{|c|}{ Quality } \\
\hline Performance quality & CQPe & 0.80 & 0.76 & & 0.36 & 0.64 & \multirow{4}{*}{0.78} \\
\hline Product Reliability & CQPro & 0.87 & 0.86 & 17.27 & 0.24 & 0.76 & \\
\hline Environmental aspect & CQEn & 0.71 & 0.75 & 13.65 & 0.50 & 0.50 & \\
\hline Certification & CQCer & 0.71 & 0.70 & 13.77 & 0.49 & 0.51 & \\
\hline \multicolumn{8}{|c|}{ Cost } \\
\hline Low costs & CCLo & 0.72 & 0.67 & & 0.49 & 0.51 & \multirow{4}{*}{0.78} \\
\hline Value added costs & $\mathrm{CCVa}$ & 0.81 & 0.74 & 13.41 & 0.35 & 0.65 & \\
\hline Quality costs & $\mathrm{CCQu}$ & 0.72 & 0.70 & 12.20 & 0.48 & 0.52 & \\
\hline Activity based measurement & CCAc & 0.73 & 0.56 & 12.38 & 0.46 & 0.54 & \\
\hline \multicolumn{8}{|c|}{ Delivery } \\
\hline Fast delivery & $\mathrm{CDFa}$ & 0.68 & 0.64 & & 0.53 & 0.47 & \multirow{4}{*}{0.82} \\
\hline Right quality & CDRi & 0.80 & 0.72 & 12.84 & 0.36 & 0.64 & \\
\hline Right amount & CDRig & 0.82 & 0.75 & 13.07 & 0.33 & 0.67 & \\
\hline Dependable promises & CDDe & 0.71 & 0.66 & 11.62 & 0.50 & 0.50 & \\
\hline \multicolumn{8}{|c|}{ Flexibility } \\
\hline Design adjustments & CFDe & 0.65 & 0.63 & & 0.57 & 0.43 & \multirow{4}{*}{0.69} \\
\hline Volume change & $\mathrm{CFVO}$ & 0.83 & 0.80 & 11.94 & 0.31 & 0.69 & \\
\hline Product Mix changes & CFPr & 0.72 & 0.70 & 10.99 & 0.48 & 0.52 & \\
\hline Broad product line & $\mathrm{CFBr}$ & 0.65 & 0.69 & 10.21 & 0.57 & 0.43 & \\
\hline \multicolumn{8}{|c|}{ Customer focus } \\
\hline After sales service & CCFA & 0.59 & 0.64 & & 0.65 & 0.35 & \multirow{4}{*}{0.55} \\
\hline Product customization & CCFPro & 0.81 & 0.81 & 11.06 & 0.34 & 0.66 & \\
\hline Customer information & CCFC & 0.81 & 0.80 & 11.07 & 0.34 & 0.66 & \\
\hline Measurement of satisfaction & CCFMea & 0.84 & 0.80 & 11.22 & 0.30 & 0.70 & \\
\hline \multicolumn{8}{|c|}{ Know-how } \\
\hline Knowledge management & CKKno & 0.73 & 0.77 & & 0.46 & 0.54 & \multirow{5}{*}{0.72} \\
\hline Continuous learning & CKCon & 0.87 & 0.89 & 16.12 & 0.24 & 0.76 & \\
\hline Problem solving skills & CKPro & 0.83 & 0.81 & 18.28 & 0.32 & 0.68 & \\
\hline Training/education & CKTr & 0.83 & 0.85 & 15.33 & 0.31 & 0.69 & \\
\hline $\mathrm{R} \& \mathrm{D}$ & CKRd & 0.71 & 0.72 & 13.00 & 0.50 & 0.50 & \\
\hline
\end{tabular}

Table 5. Second-Order Measurement Model of CP 


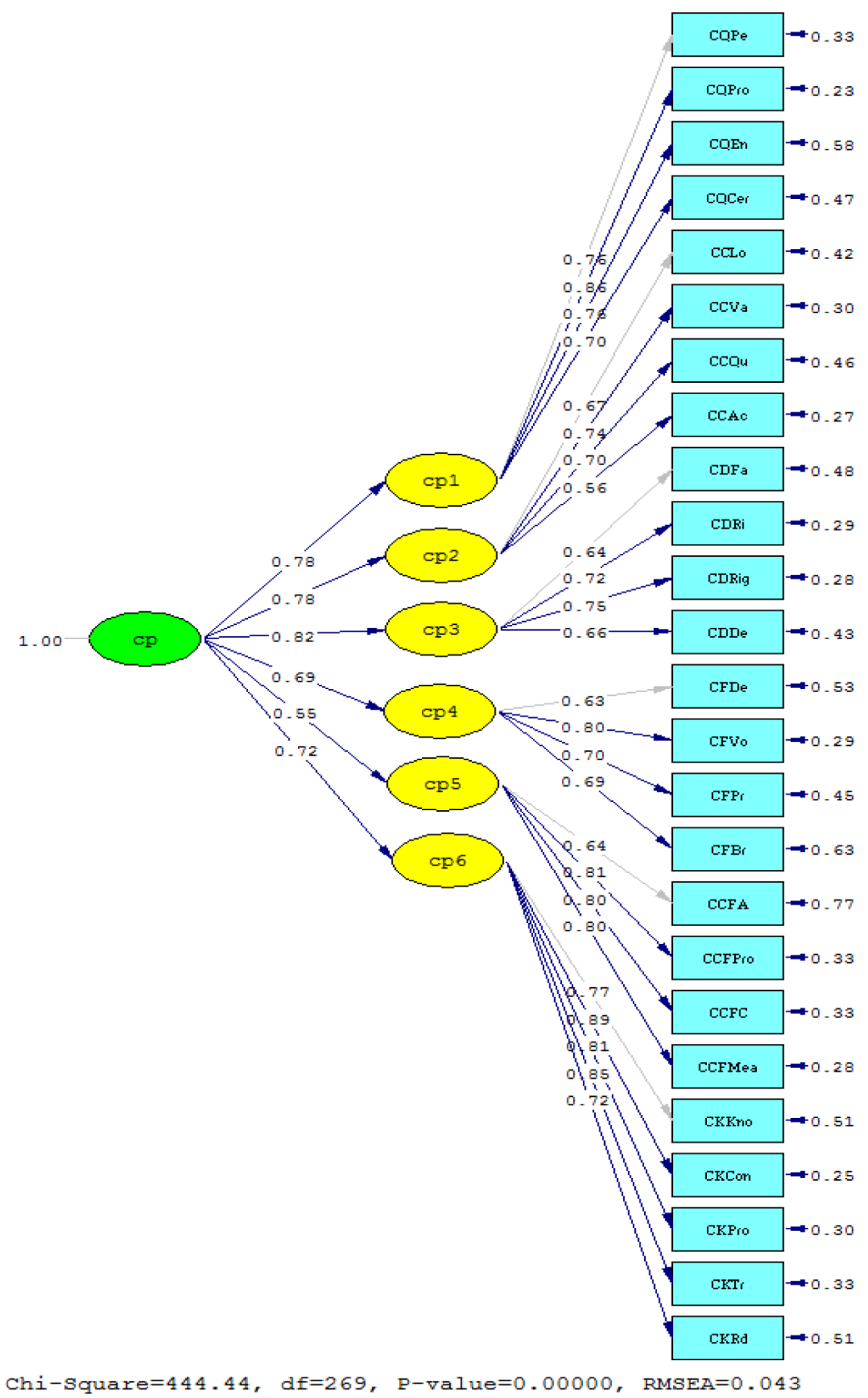

Figure 3. Second-Order Measurement Model of CP

\subsection{Descriptive Statistics of Competitive Priorities}

The mean, skewness and kurtosis values of the importance attached to each competitive priority are portrayed in the following table.

Table 6 portrays the values of mean, standard deviation, skewness and kurtosis assigned to each item in the factors, and the factors as a whole, according to their importance based on the mean score. Of the 28 variables, Activity-based measurement plays an important role as it occupies the first rank in competitive priority. This shows that the majority of the manufacturing enterprises in the Union Territory of Puducherry attach the highest preference for Activity-based measurement. Next to Activity-based measurement, the majority of the enterprises attach more importance to the Right quality as it ranks second. Problem-solving skills are ranked as third, while the 
Right amount is ranked fourth, Research \& Development is ranked fifth and Low costs are ranked as least priority among the manufacturing industries in Puducherry.

\begin{tabular}{|c|c|c|c|c|c|}
\hline SL.No & Variables & Skewness & Kurtosis & Mean & Std. Deviation \\
\hline \multicolumn{6}{|c|}{ Quality } \\
\hline 1 & Performance quality & -0.839 & 0.326 & 3.99 & 0.950 \\
\hline 2 & Product Reliability & -0.804 & 0.244 & 3.94 & 0.982 \\
\hline 3 & Environmental aspect & -0.967 & 0.379 & 3.95 & 1.079 \\
\hline 4 & Certification & -0.896 & 0.433 & 4.00 & 0.977 \\
\hline 5 & Product durability & -0.767 & 0.061 & - & - \\
\hline \multicolumn{6}{|c|}{ Cost } \\
\hline 6 & Low costs & 0.031 & -0.595 & 3.41 & 0.931 \\
\hline 7 & Value added costs & -0.426 & 0.02 & 3.64 & 0.925 \\
\hline 8 & Quality costs & -0.626 & 0.289 & 3.68 & 0.976 \\
\hline 9 & Activity based measurement & -1.146 & 0.353 & 4.45 & 0.762 \\
\hline \multicolumn{6}{|c|}{ Delivery } \\
\hline 10 & Fast delivery & -1.045 & 1.326 & 4.01 & 0.944 \\
\hline 11 & On time delivery & -1.155 & 1.279 & - & - \\
\hline 12 & Right quality & -1.305 & 1.779 & 4.23 & 0.899 \\
\hline 13 & Right amoun & -1.097 & 1.055 & 4.16 & 0.924 \\
\hline 14 & Dependable promises & -0.796 & 0.19 & 4.05 & 0.930 \\
\hline \multicolumn{6}{|c|}{ Flexibility } \\
\hline 15 & Design adjustments & -0.332 & -0.388 & 3.71 & 0.958 \\
\hline 16 & Volume change & -0.473 & -0.745 & 3.87 & 0.968 \\
\hline 17 & Product Mix changes & -0.549 & 0.127 & 3.62 & 0.970 \\
\hline 18 & Broad product line & -0.631 & -0.278 & 3.79 & 1.053 \\
\hline \multicolumn{6}{|c|}{ Customer focus } \\
\hline 19 & After sales service & -0.484 & -0.214 & 3.47 & 1.083 \\
\hline 20 & Product customization & -0.512 & -0.055 & 3.62 & 0.994 \\
\hline 21 & Customer information & -0.457 & -0.275 & 3.68 & 0.985 \\
\hline 22 & Measurement of satisfaction & -0.421 & -0.243 & 3.71 & 0.961 \\
\hline \multicolumn{6}{|c|}{ Know-how } \\
\hline 23 & Knowledge management & -0.886 & 0.345 & 3.90 & 1.051 \\
\hline 24 & Creativity & -0.953 & 0.17 & - & - \\
\hline 25 & Continuous learning & -0.996 & 0.409 & 4.09 & 1.019 \\
\hline 26 & Problem solving skills & -1.054 & 0.465 & 4.19 & 0.974 \\
\hline 27 & Training/education & -1.049 & 0.274 & 4.13 & 1.022 \\
\hline 28 & $\mathrm{R} \& \mathrm{D}$ & -1.104 & 0.512 & 4.16 & 1.009 \\
\hline
\end{tabular}

Table 6. Descriptive statistics of Competitive Priorities 


\section{Conclusion}

The research paper explains the manufacturing industries situated in the Union Territory of Puducherry. The researchers developed the measurement instrument of competitive priorities practices based on six domains namely quality, cost, delivery, flexibility, customer focus, and know-how. Of the six domains in respect of Competitive priority, delivery plays an important role followed by quality, cost, know-how, customer focus and flexibility. However, the Puducherry manufacturing firms are attaching maximum importance to delivery followed by quality, which is in contravention to the results of the study made by (Dangayach \& Deshmukh, 2005) who found that quality is the most important issue for the manufacturing firms. However, the results of this study are in absolute conformity with the results of the study of Tawfik-Mady (2008) who found out that small firms are according to maximum importance to prompt delivery followed by quality. Hence, it can be observed that the manufacturing enterprises in Puducherry are attaching the least importance to customers' focus. Regarding the delivery aspect, the right amount of product is accorded the maximum priority while the Fastness of delivery has been accorded the minimum importance. Regarding the quality aspect, Product reliability is accorded maximum importance while Certification has been accorded the least importance. Regarding the cost aspect, Value-added costs have been accorded the highest priority while Activity-based measurements have been assigned the least importance. Regarding the Know-how aspect of Comparative Priority, Continuous learning has been accorded the highest importance while Research and development have been accorded the least importance. With regard to the flexibility aspect, the volume change of machinery has been assigned the highest importance while design adjustments have been accorded the least importance. Finally, regarding the Customer focus domain, measurement of Product customization has been assigned the highest importance while the least importance has been accorded to the Aftersale services.

\section{Declaration of Conflicting Interests}

The authors declared no potential conflicts of interest with respect to the research, authorship, and/or publication of this article.

\section{Funding}

The authors received no financial support for the research, authorship, and/or publication of this article.

\section{References}

Avella, L. (1999). Focal points in manufacturing strategic planning in Spain Comparison with American and other European manufacturers. International Journal of Operations \& Production Management, 19(12), 1292-1317. https://doi.org/10.1108/01443579910294246

Barclay, D., Higgins, C., \& Thompson, R. (1995). The partial least squares (PLS) approach to causal modelling: personal computer adoption and use as an illustration. Technology Studies, 2(2), 285-324.

Baumgartner, H., \& Homburg, C. (1996). Applications of Structural Equation Modeling in Marketing and Consumer and Research: A Review. International Journal of Research in Marketing, 13(2), 139-161. https://doi.org/10.1016/0167-8116(95)00038-0

Bentler, P.M. (1992). EQS: Structural Equations Program Manual. Los Angeles: BMDP Statistical Software.

Boyer, K.K., \& Pagell, M. (2000). Measurement issues in empirical research: improving measures of operations strategy and advanced manufacturing technology. Journal of Operations Management, 18, 361-374. https://doi.org/10.1016/S0272-6963(99)00029-7

Byrne, B.M. (1988). The Self Description Questionnaire III: Testing for equivalent factorial validity across ability. Educational and Psychological Measurement, 48, 397-406. https://doi.org/10.1177/0013164488482012

Camisón, C., \& Villar López, A. (2010). An examination of the relationship between manufacturing flexibility and firm performance: The mediating role of innovation. International Journal of Operations \& Production Management, 30(8), 853-878. https://doi.org/10.1108/01443571011068199 
Carmines, E.G., \& Zeller, R.A. (1979). Reliability and Validity Assessment. Newbury Park, CA: Sage. https://doi.org/10.4135/9781412985642

Carpinetti, L.C.R., Gerolamo,M.C., \& Dorta, M. (2000). A conceptual framework for deployment of strategy-related continuous improvements. The TQM Magazine, 12(5), 340-349. https://doi.org/10.1108/09544780010341950

Chin, W.W. (1998). The partial least squares approach to structural equation modelling. In Marcoulides, G.A. (Ed.), Modern Methods for Business Research (295-336). Mahwah, NJ: Lawrence Erlbaum Associates.

Dangayach, G.S., \& Deshmukh S.G. (2003). Evidence of manufacturing strategies in Indian industry: a survey. International Journal of Production Economics, 83, 279-298. https://doi.org/10.1016/S0925-5273(02)00372-9

Dangayach G.S., \& Deshmukh S.G. (2005). Advanced manufacturing technology implementation Evidence from Indian small and medium enterprises (SMEs). Journal of Manufacturing Technology Management, 16(5), 483-496. https://doi.org/10.1108/17410380510600473

Deming, W.E. (1986). Out of Crisis, Cambridge, MA: MIT Center for Advanced Engineering Study (Cambridge, MA) and Gitlow and Gitlow, The Deming Guide to Quality and Competitive Position (1987). Englewood Cliffs, NJ: Prentice-Hall.

Deming, W.E. (1982). Quality, Productivity and Competitive Position. Cambridge, MA: MIT Center for Advanced Engineering Study.

Everitt, B. (2006). The Cambridge dictionary of statistics (3rd ed.). Cambridge, UK, New York: Cambridge University Press.

Ferdows, K., \& De Meyer, A. (1990). Lasting improvements in manufacturing performance: in search of a new theory. Journal of Operations Management, 9(2), 168-83. https://doi.org/10.1016/0272-6963(90)90094-T

Fornell, C., \& Larcker, D. (1981). Evaluating structural equation models with unobservable variables and measurement error. Journal of Marketing Research, 18(1), 39-50. https://doi.org/10.1177/002224378101800104

Ganeshkumar, C., Prabhu, M., \& Abdullah, N.N. (2019). Business Analytics and Supply Chain Performance: Partial Least Squares-Structural Equation Modeling (PLS-SEM) Approach. International Journal of Management and Business Research, 9(1), 91- 96.

Groebner, D.F., \& Shannon, P.W. (1990). Business statistic: a decision-making approach (3rd ed.). New York: Macmillian Publishing Company.

Haeri, A.G. (2005). Total quality management in an Iranian Auto Part Manufacture: The case of "RAFA". Master of Art dissertation, 1-68.

Hair, J.F., Black, W.C., Babin, B.J., Anderson, R.E., \& Tatham, R.L. (2006). Multivariate data analysis (6th ed.). Upper Saddle River, NJ: Pearson Prentice Hall.

Hair, J.F., Anderson, R.E., Tatham, R.l., \& Black, W.C. (1998). Multivariate Data Analysis (5th ed.). Englewood Cliffs, NJ: Prentice-Hall International.

Hayes, R., \& Wheelwright, S. (1984). Restoring Our Competitive Edge: Competing Through Manufacturing. New York, NY: Wiley.

Ibrahim, S.E. (2010). An alternative methodology for formulating an operations strategy: the case of BTC-Egypt. Management Decision, 48(6), 868-893. https://doi.org/10.1108/00251741011053442

Jarvis, C.B., MacKenzie, S.B., \& Podsakoff, P.M. (2003). A critical review of construct indicators and measurement model misspecification in marketing and consumer research. Journal of Consumer Research, 30(2), $199-218$. https://doi.org/10.1086/376806

Jöreskog, K.G., \& Sörbom, D. (1996). Lisrel 8: User's Reference Guide. Chicago, IL: Scientific Software International, Inc..

Jöreskog, K.G., \& Sorbom, D. (1993). New Features in LISREL 8. Chicago: Scientific Software. 
Kathuria, V. (2000). Productivity spillovers from technology transfer to Indian manufacturing firms. Journal of International Development, 12(3), 343-369. https://doi.org/10.1002/(SICI)1099-1328(200004)12:3<343::AIDJID639>3.0.CO;2-R

Kathuria, R., Porth, S.J., \& Joshi, M.P. (1999). Manufacturing priorities: do general managers and manufacturing managers agree?. International Journal of Production Research, 37(9), 2077-2092.

https://doi.org/10.1080/002075499190914

Kathuria, R., Porth, S.J., \& Kathuria, N.N. (2010). Competitive priorities and strategic consensus in emerging economies: evidence from India. International Journal of Operations \& Production Management, 30(8), 879-896. https://doi.org/10.1108/01443571011068207

Kim, J.S., \& Arnold, P. (1996). Operationalising manufacturing strategy: an exploratory study of constructs and linkage. International Journal of Operations \& Production Management, 16(12), 45-73.

https://doi.org/10.1108/01443579610151751

Krajewski, L.J., \& Ritzman, L.P. (1993). Operations Management: Strategy and Analysis (3rd ed.). Wokingham: Addison-Wesley.

Lewis-Beck, M.S., Bryman, A., \& Liao, T. (2004). The Sage encyclopedia of social science research methods (3 vols.). Thousand Oaks, Ca: Sage. https://doi.org/10.4135/9781412950589

Li, P., Qi, Z.I., Tian, Y.Z., \& Li, Z. (2008). An Empirical Study on the Cumulative Relationship of Competitive Priorities in Chinese Manufacturing Enterprises. International Conference on Management Science \& Engineering (15th), Long Beach, USA, September 10-12. https://doi.org/10.1109/ICMSE.2008.4668929

Li, L. (2000). Manufacturing capability development in a changing business environment. Industrial Management \& Data Systems, 100(6), 261-70. https://doi.org/10.1108/02635570010301188

Mojtahedzadeh, R., \& Arumugam, V.C. (2011). Determinants of TQM in the Iranian Automotive Industry: A Theoretical Approach. International Journal for Quality research, 5(1).

Motwani, J.G., Mahmoud, E., \& Rice, G. (1994). Quality practices of Indian organization: An empirical analysis. International Journal of Quality and Reliability Management, 11, 38-52. https://doi.org/10.1108/02656719410049493

Nagabhushana, T.S., \& Shah, J. (1999). Manufacturing priorities and action programmes in the changing environment An empirical study of Indian industries. International Journal of Operations \& Production Management, 19(4), 389-398. https://doi.org/10.1108/01443579910254240

Nambirajan, T., \& Prabhu M. (2010). Determinants of Competitiveness of Small-Scale Industries in Union Territory of Puducherry. Advances in Management, 3(5), 46-49.

Phusavat, K., \& Kanchana, R. (2008). Future competitiveness: viewpoints from manufacturers and service providers. Industrial Management \& Data Systems, 108(2), 191-207. https://doi.org/10.1108/02635570810847572

Phusavat, K., \& Kanchana, R. (2007). Competitive priorities of manufacturing firms in Thailand. Industrial Management and Data Systems, 7(7), 979-996. https://doi.org/10.1108/02635570710816702

Shim, S., Eastlick, M.A., Lotz, S.L., \& Warrington, P. (2001). An online prepurchase intentions model: the role of intention to search. Journal of Retailing, 77, 397-416. https://doi.org/10.1016/S0022-4359(01)00051-3

Sudhakar, R., \& Basariya, S.R. (2017). Perspectives and the Factors Influencing Effectiveness of Training and Development on Employees' Performance. International Journal of Civil Engineering and Technology, 8(9), $135-141$.

Tabachnick, B.G., \& Fidell, L.S. (2007). Using multivariate statistics (5th ed.). Boston: Pearson/Allyn \& Bacon.

Tawfik-Mady, M. (2008). The impact of plant size and type of industry on manufacturing competitive priorities, An empirical investigation. Competitiveness Review: An International Business Journal, 18(4), 351-366.

https://doi.org/10.1108/10595420810920824 
Vickery, S.K., Droge, C., \& Markland, R.E. (1993). Production competence and business strategy: do they affect business performance. Decision Sciences, 24(2), 435-55. https://doi.org/10.1111/j.1540-5915.1993.tb00482.x

Ward, P., \& Duray, R. (2000). Manufacturing strategy in context: environment, competitive strategy and manufacturing strategy. Journal of Operations Management, 18(2), 123-138. https://doi.org/10.1016/S02726963(99)00021-2

Wheelwright, S.C. (1984). Manufacturing strategy: Defining the missing link. Strategic Management Journal, 5(1), 77-91. https://doi.org/10.1002/smj.4250050106

Wood, C.H., Ritzman, L.P., \& Sharma, D. (1990). Intended and achieved competitive priorities: measures, frequencies, and financial impact. In Ettlie, J., Burstein, E., \& Fiegenbaum, M.C. (Eds.), Manufacturing Strategy (225-232). Boston, MA: Kluwer Academic Publishers. https://doi.org/10.1007/978-94-009-2189-4_22

Zhao, X., Yan Yeung, J.H., \& Zhou, Q. (2002). Competitive priorities of enterprises in mainland China. Total Quality Management, 13(3), 285- 300. https://doi.org/10.1080/09544120220135174

\section{Annex A}

\section{Competitive Priorities}

State the level of priority attached to the following Competitive Priority issues by your enterprise in a Likert's five-point scales of ( 1 =Very Low Priority, 2 =Low Priority, 3 = Moderate Priority, 4 = High Priority, 5 = Very High Priority)

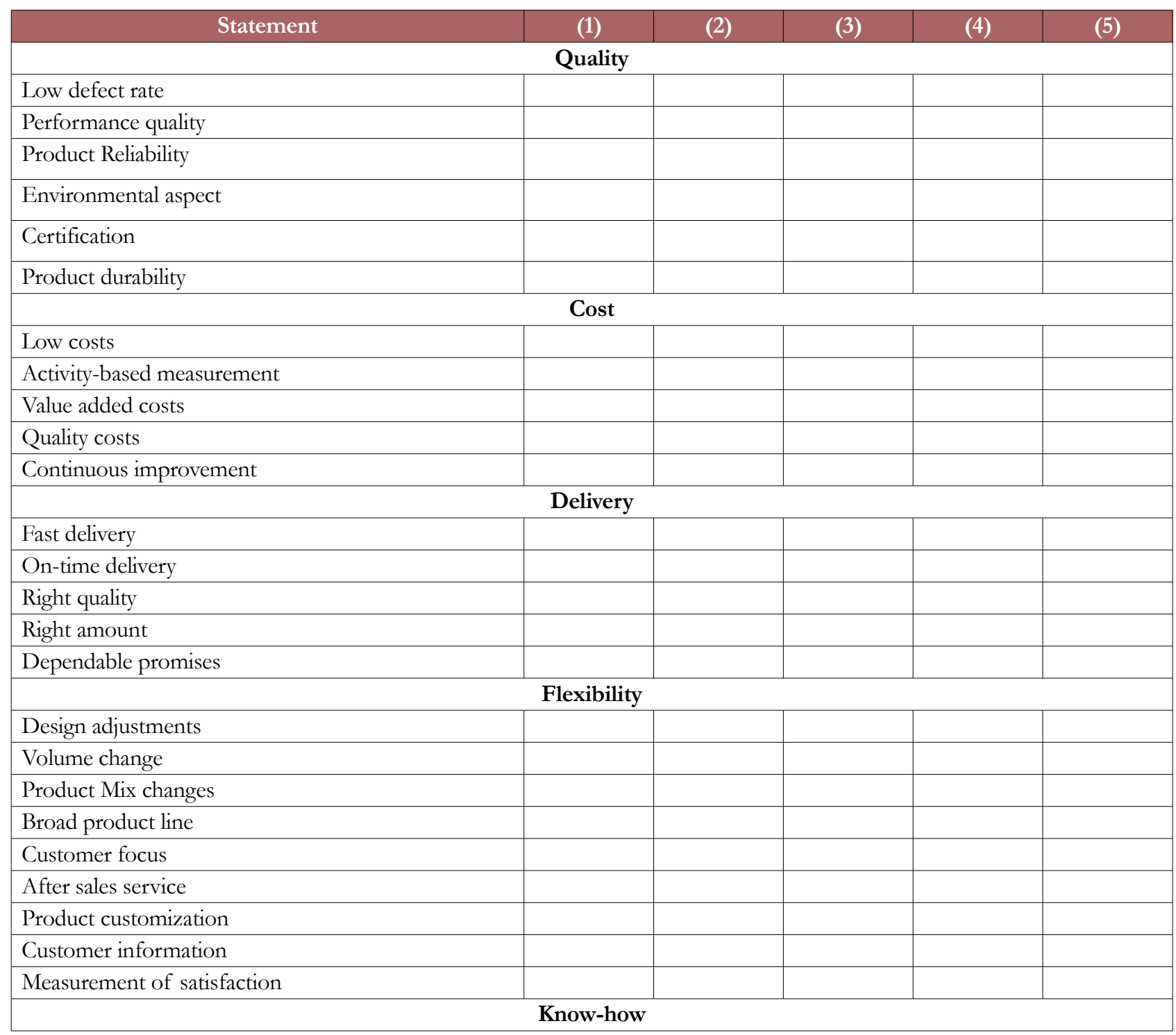




\begin{tabular}{|l|l|l|l|l|l|}
\hline \multicolumn{1}{|c|}{ Statement } & (1) & (2) & (3) & (4) & (5) \\
\hline Knowledge management & & & & & \\
\hline Creativity & & & & & \\
\hline Continuous learning & & & & & \\
\hline Problem solving skills & & & & & \\
\hline Training/education & & & & & \\
\hline R\&D & & & & & \\
\hline
\end{tabular}

Journal of Industrial Engineering and Management, 2020 (www.jiem.org)

\section{() $(1) \Theta$}

Article's contents are provided on an Attribution-Non Commercial 4.0 Creative commons International License. Readers are allowed to copy, distribute and communicate article's contents, provided the author's and Journal of Industrial Engineering and Management's names are included. It must not be used for commercial purposes. To see the complete license contents, please visit https://creativecommons.org/licenses/by-nc/4.0/. 